\title{
IMPRESSIONS OF A FRENCHMAN ABOUT THE BALKANS IN THE XVIII CENTURY
}

(Dalibor Elezović, Balkans in letters: the impressions of an 18th-century Westerner. Sofia: Bulgari Publishing House; Kosovska Mitrovica: Faculty of Philosophy, 2019, 212 pp.)

Abstract: The paper gives an overview of Dalibor Elezovićs book Balkans in letters: the impressions of an 18th-century Westerner. It is about the book based on epistolary material, created from the pen of an unknown Frenchman who toured the Balkans in the eighteenth century. The book deals with the study of epistolary discourse, which is a current issue of contemporary historical science and other social sciences. The focus is on the importance of letters from a Westerner on the image of the Balkans in the eighteenth century since there

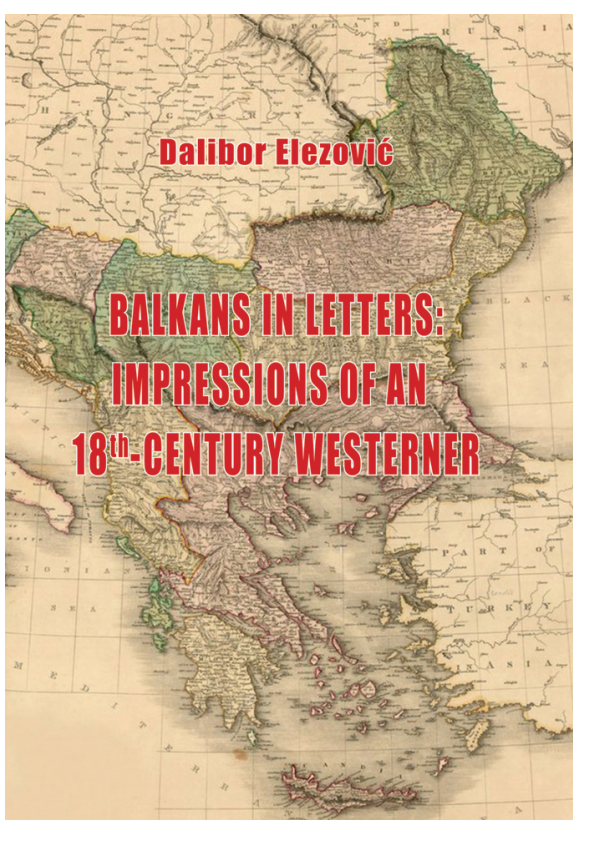

${ }^{1}$ galunov@abv.bg are not many sources of similar content.

Keywords: Balkans in the eighteenth century, epistolary material, historiography, Dalibor Elezović

A valuable book by historian Dalibor Elezovic has emerged from the press, dealing with a description of the Balkans given in letters from an anonymous Westerner from the XVIII century. We especially emphasize the fact that the book was created as a result of the work of the author on the scientific project Religion, National Identity and Statehood in the Balkans, XIX - XXI century, realized by the Faculty of History of Veliko Tarnovo University of St. Cyril and Methodius.This data shows the good practice of cooperation of Balkan scientists and the realization of 
research on the past of this region. The publishers of the book are Sofia Bulgari Publishing House and Faculty of Philosophy in Kosovska Mitrovica.

In the book, the author emphasizes two problematic discourses. The first is epistolary discourse, which is of great interest during the early modern times because it was so popular that it was used in various creative genres. The early modern era represented a time when letter writing and letter communication experienced the greatest development. It is therefore not surprising that the traveler chose this particular form of storytelling to record his observations and reflections while traveling the Balkans. By the way, the XVIII century was the era when the epistolary culture, in general, experienced the greatest upsurge, and a good confirmation of this is the collection of letters, which was the subject of analysis by the author in this book. This epistolary collection testifies that, in this period, letters were collected, classified and compiled into books, thus providing an opportunity for future generations to become acquainted with both the culture of writing letters and the important historical facts of the time. According to Elezovic, the epistolary source he was researching allowed him to become familiar with the thinking of a Westerner in the first place, about the way he experienced the Balkans and transmitted it to paper. The pressure of a different environment, from the one he knew, and of a foreign mentality, often directed the Westerners towards deep thoughts, and sometimes even caused some fear in him (Elezović, 2019, pp. 14-15). The second discourse that Elezovic emphasizes is the importance of the epistolary source explored in the context of the fact that there are not many such narratives for the Balkans, as is the case with, say, Western Europe. Therefore, the processing and reconstruction of the image provided by this source were essential for understanding the Balkan past, primarily in a cultural context at the time indicated. Particularly interesting are the places that touch on some of the current Balkan issues - issues of identity and cultural diversity.

The fact that gives quality to this book is that its primary source has not been addressed so far by Balkan historiography. Bulgarian historiography has paid great attention to the importance of travelogues for the history of the Balkan region, and a large number of these works have been published by travelers from the West. The well-known Bulgarian historian Bistra Cvetkova dealt with this issue. She published significant works from the travelogue of foreigners in the Balkans in the new century but did not cite a source that Elezovic used (Tsvetkova, 1975). Other Bulgarian researchers who have done similar research do not cite a source that is primary in Elezovic's research (Jonov, 1979).

The book helps to understand and shed light on the orientalization of the Balkans at a time after this process culminated in the Balkans in connection with the conquest of the Ottoman Empire. The panorama of the Balkans presented by a Westerner, as well as the wider context of the image he acquired of this space and its culture in general, depicts the attitude of a European towards, most culturally, space which is not known to him; though geographically close. This fits in with studies of European modern history, that is, the dynamics of the European cultural spirit and its spread - the phenomenon of culture, science, and its cultural manifestation, the collisions and symbioses between religion and culture (Pantev, Glushkov, Mishev, 2010).

The space covered by the author in the book is a wider expanse of the Balkan region, a territory that was divided between the Ottoman Empire, the Habsburg Monarchy and Venice. The author was holding on this unique historical space so the work involves also the part of the territory of Hungary, Wallachia, and Moldova, as well as a small part of Asia 
Minor Turkey. In the contours of the wider Balkans, Elezovic rightly framed the so-called "European Turkey", the South Slavic countries, parts of Hungary under the Ottoman rule and the Danube principality.

The book also provides a picture of Bulgaria given by the Frenchman in his letters; Travelers' impressions are no less interesting when it comes to Bulgaria and the Bulgarians, and their oldest past that he was particularly interested in.Bulgarians have been described as a nation with a glorious history, known for the military successes, breakthroughs, and devastation of countries that would have come their way during the Middle Ages. The description of the roots of the Bulgarians is also valuable, which states that "all Bulgarians have the same origin". Their common ancestral homeland Westerner calls the Great Bulgaria, which extends into the region of the Don Delta. Another important cultural aspect that has been the common denominator of the inhabitants of the Bulgarian area is that their religion is Christianity, and their priests listened to the prelates who acknowledged the Patriarch in Constantinople. Also interesting is the description of the organization of the Bulgarian Church at that time. Church dignitaries leased the parish from their priest and made the villagers obliged to contribute to their baptisms and weddings. The book also provides a description given by the Frenchman of the origin of the Albigensian heresy, which he claimed to be rooted in Bulgaria (Elezovic, 2019, p. 111-114).

In the book, we also find a segment related to the image of the Holy Mountain (Sveta gora) given by the Frenchman in his letter and from which it can be seen that he was interested in this unique monastic community. For the French, the Holy Mountain was one of the most interesting parts of the Balkans. He noted that in the summer, before sunset, its shadow stretched to Lemnos Island, which is very far from it. He describes the Mountains of the Holy Mountain that continue on top of one another and form a mountain range that "merges with Macedonia". The Frenchman also writeson Holy Mountain and that more than six thousand monks lived in them. After the service, they engaged in manual jobs daily: some cultivated vineyards and olive groves, others worked as carpenters, stone processors, masons, weavers, etc. (Elezović, 2019, p. 96-100).

A significant part of the book refers to the image of the Ottoman Empire that the Frenchman depicted in the letters. It is a description of Constantinople and Edirne, then Thessaloniki, Izmir, and other Turkish cities and regions. As a distinguished man, the French auditioned with the French ambassador in Constantinople at the Sultan. He got acquainted with customs, culture, the relationship between man and woman and other phenomena of the Turkish state of that time. There is an interesting observation of an anonymous traveler about the top of the Turkish state hierarchy, where there was a constant struggle over power and no one was sure how long he would survive in his position. It was ensured that individuals did not gain too much power and lose control, and when they did, the Sultan resorted to the custom of giving that man one of his princesses for a wife.

The author deals with the essential issues of analysis of the epistolary source in the book and has found with the critical interpretation that in many places in the letters, the anonymous Frenchman gives subjective ratings and representations of the Balkan space. On the other hand, he also found that he had objective views on many interesting issues of the Balkan cultural mosaic.He came to the conclusion that for the historiography are important places in the source that in a special way touch on some always current Balkan issues, such as issues of identity, language, culture, religion, tradition, customs, as well as 
issues of tolerance and coexistence of different communities in the colorful soil of the Balkan Peninsula.Interesting are the parts that present the older history of the Balkans and which raise some issues that have been debated in science; bringing Sarmats and the Slavs together, as well as the story that the Slavs crossed the Danube in the time of Emperor Justinian. Also interesting are the moments where the French man cites the extraordinary customs of Vlachs and Morlachs and their unusual mentality (Elezović, 2019, p. 162-170).

We can conclude that the author of the book (using modern scientific methods in a complex analysis of the epistolary source) was able to provide the text with the answer to the question how someone who came from the West sees the Balkans between the thirties and the fifties of the XVIII century.The book provides the reader with information about the Balkan country, the Balkan peoples, their culture and everyday life, in a word, "the impressions of an eighteenth-century Westerner," as it is stated in the title.It remains for us at the end of this review to gladly recommend Dalibor Elezovic's book to a scholarly, but also a wide readership, as it contains interesting information for readers of different appetites. We would once again commend the implementation of this book within the framework of the cooperation of the Balkan scientific community and international publishing projects, as a good example to be followed and promoted. 
Тодор Галунов ${ }^{1}$

Великотрновски универзитет “Свети Ћирило и Методије”

Филозофски факултет

Велико Трново (Бугарска)

\title{
УТИСЦИ ЈЕДНОГ ФРАНЦУЗА О БАЛКАНУ 18. ВЕКА
}

\author{
Dalibor Elezović, Balkans in letters: the impressions \\ of an 18th-century Westerner. Sofia: Bulgari Publishing House; \\ Kosovska Mitrovica: Filozofski fakultet, 2019, 212 str.
}

(Превоg In Extenso)

Сажетак: Овај рад даје преглед књиге Далибора Елезовића Balkans in letters: the impressions of an 18th-century Westerner. Говори о књизи заснованој на епистоларном материјалу из пера непознатог Француза на пропутовању Балканом у осамнаестом веку. Књига се бави изучавањем епистоларног дискурса у фокусу савремене науке о историји и осталих наука. Усредсређен је на значај писама једног западњака о слици Балкана у осамнаестом веку, с обиром на то да не постоји много извора сличног садржаја.

Кључне речи: Балкан у осамнаестом веку, епистоларни материјал, историографија, Далибор Елезовић

Из штампе је изашла драгоцена књига историчара Далибора Елезовића која говори о опису Балкана датом у писмима непознатог западњака из XVIII века. Посебно истичемо чињеницу да је књига настала као резултат ауторовог рада на научном

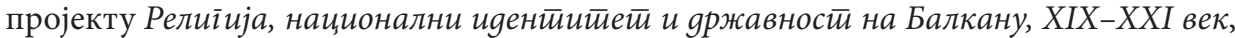
спроведеном на Факултету за историју Универзитета „Св. Ћирило и Методије” у Великом Трнову. Ови подаци говоре о доброј пракси сарадње балканских научика и спровођења истраживања о прошлости овог региона. Издавачи књиге су Bulgari Publishing House из Софије и Филозофски факултет у Косовској Митровици.

Аутор књиге наглашава два спорна дискурса. Први је епистоларни дискурс, који изазива велико интересовање на почетку савременог доба због тога што је био тако популаран да је коришћен у разним стваралачким жанровима. Рано савремено доба представља време када су писање писама и комуникација путем писама доживели најснажнији развој. Стога не изненађује то што је путник одабрао овај својеврсни облик приповедања како би забележио своја запажања и размишљања док је путовао по Балкану. Осим тога, XVIII век био је доба када је епистоларна култура уопште доживела највећи успон, што одлично потврђује и збирка писама као предмет ауторове анализе у овој књизи. Та епистоларна збирка сведочи о томе да су у датом периоду писма сакупљана, разврставана и повезивана у књиге, дајући наредним нараштајима при-

\footnotetext{
${ }^{1}$ galunov@abv.bg
} 
лику да се упознају како са културом писања писама, тако и са значајним историјским чињеницама тога доба. Према Елезовићу, епистоларни извор који је истраживао омогућио му је да се упозна са размишљањима једног западњака, пре свега, о начину на који је доживео Балкан и то пренео на папир. Притисак другачијег окружења од оног какво је познавао, као и страног менталитета, често је западњака наводио на дубоке мисли, а понекад у њему изазивао чак и извесну дозу страха (Elezović, 2019, str. 14-15). Други дискурс који Елезовић истиче јесте значај епистоларног извора истраженог у контексту чињенице да не постоји много оваквих повести о Балкану као што је случај, рецимо, са Западном Европом. Стога су обрада и реконструкција слике из овог извора биле прсудне за разумевање прошлости Балкана, првенствено у културном контексту датог доба. Нарочито су занимљива места која се баве појединим текућим питањима на Балкану - питањима идентитета и културне разноликости.

Оно што ову књигу чини квалитетном јесте то што се њен примарни извор до сада не помиње у балканској историографији. Бугарска историографија придаје велику пажњу значају путописа у историји балканског региона, а велики број тих радова објавили су путници са Запада. Овом темом бавила се позната бугарска историчарка Бистра Цветкова. Објавила је значајне радове о путописима странаца на Балкану у савремено доба, али није цитирала извор који обрађује Елезовић (Tsvetkova, 1975). Остали бугарски научници бавили су се сличним истраживањима, али не наводе извор који је примаран у Елезовићевом раду (Jonov, 1979).

Књига нам помаже да схватимо и расветљава оријентализацију Балкана у време када је овај процес достигао врхунац на Балкану након што га је освојило Османско царство. Панорама Балкана коју приказује овај западњак, као и шири контекст слике коју је стекао о овом простору и култури представља став Европљанина према простору који му, пре свега у културолошком смислу, није био познат, упркос географској близини. Ово се уклапа у студије европске модерне историје, то јест, динамике европског културног духа и његове распрострањености - феномена културе, науке и њене културолошке манифестације, сукоба и симбиоза између религије и културе (Pantev, Glushkov, Mishev, 2010).

Простор који аутор покрива у књизи је Балкан у ширем смислу, територија подељена између Османског царства, Хабзбуршке монархије и Венеције. Аутор се држао овог јединственог историјског простора како би рад обухватио и део територије Мађарске, Влашке и Молдавије, као и један део Мале Азије. У оквиру ширег Балкана Елезовић је с правом обухватио такозвану европску Турску, јужнословенске земље, делове Мађарске под османском влашћу и Дунавску кнежевину.

Књига такође даје слику Бугарске коју је Француз представио у својим писмима; утисци путописца нису ништа мање интересантни ни када је реч о Бугарској и Бугарима, а нарочито о њиховој најстаријој прошлости, за коју је показивао посебно интересовање. Бугари су описани као народ са славном историјом, познати по војним успесима, походима и покоравању земаља које су им се нашле на путу током средњег века. Опис бугарских корена такође је драгоцен јер наводи да „сви Бугари имају исто порекло“. Заједничку постојбину њихових предака Француз назива Великом Бугарском која се простирала у региону делте Дона. Још један значајан културолошки аспект као заједнички именилац становника Бугарске јесте то што су они хришћани, а њихови свештеници су слушали прелате који признају патријарха 
у Константинопољу. Занимљив је и опис организације цркве у Бугарској тога доба. Црквени великодостојници су закупљивали парохију од свог свештеника и присиљавали сељаке да им дају прилоге за крштење и венчања. Ова књига такође преноси како Француз описује порекло албигенске јереси, за коју тврди да је укорењена у Бугарској (Elezović, 2019, str. 111-114).

У књизи се налази и сегмент о приказу Свете горе који Француз даје у свом писму и из којег се може видети његово интересовање за ову јединствену монашку заједницу. За Француза је Света гора представљала један од најзанимљивијих делова Балкана. Забележио је како се лети, пре заласка сунца, сенка Свете горе простирала све до острва Лимнос, које је прилично удаљено. Он описује како се планине Свете горе надовезују једна на другу и стварају планински венац који се „спаја са Македонијом“. Француз такође пише да је на Светој гори живело више од шест хиљада монаха. После службе, они су се свакодневно бавили физичким пословима: неки су обрађивали винограде и маслињаке, а други су радили као столари, каменоресци, зидари, ткачи итд. (Elezović, 2019, str. 96-100).

Значајан део књиге односи се на слику коју је Француз приказао о Османском царству у својим писмима. Описује Константинопољ и Једрене, затим Солун, Измир и остале турксе градове и области. Као угледан човек, овај Француз је са француским амбасадором био у аудијенцији код султана у Константинопољу. Упознао се са обичајима, културом и односом између мушкараца и жена, као и са осталим појавама у турској држави тога доба. Ту је и занимљиво запажање непознатог путника о врху хијерархије у турској држави, где се води непрекидна борба за власт и нико није сигуран колико ће опстати на свом положају. Водило се рачуна о томе да појединци не стекну превише власти и изгубе контролу, а уколико би се то догодило, султан је прибегавао обичају да тог човека ожени једном од својих кћери.

Аутор се бави основним питањима анализе епистоларног извора у књизи и критичким тумачењем открива да на многим местима у писмима непознати Француз даје субјективне оцене и приказе балканског простора. С друге стране, такође је утврдио да Француз има објективне погледе о бројним занимљивим питањима из културног мозаика Балкана. Дошао је до закључка да су за историографију значајна она места у извору која на посебан начин говоре о увек горућим балканским проблемима, као што су идентитет, језик, култура, религија, традиција, обичаји, као и питања толеранције и суживота разних заједница на шароликом тлу Балканског полуострва. Интересантни су делови који говоре о старијој историји Балкана и покрећу питања о којима се води научна расправа; повезивање Сармата и Словена, као и прича да су Словени прешли Дунав у доба владавине импреатора Јустинијана. Занимљиви су и тренуци када Француз помиње чудне обичаје Влаха и Морлака и њихов необичан менталитет (Elezović, 2019, str. 162-170).

Можемо закључити да је аутор књиге (користећи модерне научне методе у сложеној анализи епистоларног извора) успео да напише текст са одговором на питање о томе како је неко са запада видео Балкан тридесетих и четрдесетих година XVIII века. Књига пружа читаоцу информације о балканским земљама и народима, њиховој култури и свакодневном животу, једном речју, „утиске западњака из осамнаестог века", као што је и наведено у наслову. Преостаје нам да на крају овог приказа топло препоручимо књигу Далибора Елезовића како стручњацима, тако и широкој 
читалачкој публици јер садржи интересантне податке за читаоце различитих сфера интересовања. Још једном ћемо похвалити то што је ова књига написана у оквиру сарадње балканске научне заједнице и међународних издавачких пројеката, као добар пример који треба следити и поштовати.

\section{REFERENCES / ЛИTEPATУPA}

Tsvetkova, B. (1975). French travelogues for the Balkans: XV-XVIII centuries. Sofia: Science and Art [In Bulgarian]

Elezović, D. (2019). Balkans in letters: the impressions of an 18th-century Westerner. Sofia: Bulgari PH; Kosovska Mitrovica: Filozofski fakultet Univerziteta u Prištini

Genchev, Nikolai, Bulgarian Revival. Sofia: East-West, 2010. [In Bulgarian]

Jonov, M. (1979).German and Austrian travelogues for the Balkans: XV-XVI c. Sofia: Science and Art [In Bulgarian]

Pantev, A., Glushkov, H., Mishev, R. (2010). History of the Modern World.V. Tarnovo: Abagar [In Bulgarian] 